\title{
Morphological and molecular characteristics of foliar nematode attacking silver birch (Betula pendula Roth) in Poland
}

\author{
A. CHALAŃSKA ${ }^{1 *}$, A. BOGUMIt ${ }^{2}$, G. WINISZEWSKA ${ }^{3}$, K. KOWALEWSKA $^{4}$, T. MALEWSKI $^{5}$
}

\begin{abstract}
${ }^{1 *}$ Research Institute of Horticulture, Konstytucji 3 Maja 1/3, 96-100 Skierniewice, Poland, E-mail: aneta.chalanska@inhort.pl; ${ }^{2}$ Research Institute of Horticulture, Konstytucji 3 Maja 1/3, 96-100 Skierniewice, Poland, E-mail: aleksandra.bogumil@inhort.pl; ${ }^{3}$ Museum and Institute of Zoology, Wilcza 64, 00-679 Warsaw, Poland, E-mail: nicien@miiz.waw.pl; 4Museum and Institute of Zoology, Wilcza 64, 00-679 Warsaw, Poland, kkowalewska@miiz.waw.pl; ${ }^{M}$ Museum and Institute of Zoology, Wilcza 64, 00-679 Warsaw, E-mail: tmalewski@miiz.waw.pl
\end{abstract}

Article info

Received November 9, 2015 Accepted May 2, 2017

\begin{abstract}
Summary
Aphelenchoides fragariae (Ritzema Bos, 1890) Christie, 1932 was isolated from leaves of silver birch (Betula pendula Roth) seedlings proving that the source of infection was anemones plants. This is the first report to our best knowledge showing that the source of nematode infection of a woody plant could be a perennial plant. $A$. fragariae was identified by morphometric and molecular analyses. Morphological diagnosis based on the bending shape of the tail of males and pronounced apex and rostrum proved to be the most accurate reliable characteristic. On the opposite, the high variability of the mucron shape in female tails made the identification by microscopic analyses difficult. Identification of the species was confirmed by analysis of $28 \mathrm{~S}$ rDNA sequences. The morphometric data of adults extracted from silver birch was compared with that of nematodes isolated from Anemone hupehensis (Lemoine) Lemoine. Males body length varied highly in samples collected from both host plant species.
\end{abstract}

Keywords: Aphelenchoides fragariae; woody plant; morphometric data; 28S rDNA

\section{Introduction}

Strawberry foliar nematode (Aphelenchoides fragariae) (Ritzema Bos, 1891) Christie, 1932 is a widespread plant pest that has been reported on a very large number of hosts: including shrubs (e.g. Weigela subsessilis (Nakai) L.H.Bailey) (Khan et al., 2007a), perennials (e.g. Hosta sp. Tratt. (Noel \& White, 1994), Lamium maculatum L. (LaMondia \& Ocamb, 1995), Helianthus tuberosus L. (Khan et al., 2007a), Stachys riederi Cham. (Khan et al. 2008), Anthurium andraeanum Linden ex André (Hunter et al., 1974)) and trees (e.g. Ficus macrophylla Pers. (Penrose \& Nikandrow, 1971)). In Poland $A$. fragariae was found only on Fragaria $\times$ ananassa Duchesne (Szczygieł, 1963; 1966; 1970). Nematodes from Aphelenchoides species infecting trees were detected mostly in association with stem deformations, such as dogwood cankers (Santamour \& McArdle, 1987; Self \& Bernard, 1994). In September of 2014 a silver birch (Betula pendula Roth) seedling with brown necrotic areas in proximity of the major veins of leaves was observed at the experimental field of the Research Institute of Horticulture in Skierniewice in a plot managed with overhead irrigation. The aim of our study was to identify the causative factor of these symptoms and to determine their source.

\section{Materials and Methods}

Isolation and morphological examination of nematodes In 2014 silver birch (Betula pendula Roth) seedlings were grown on the experimental field of the Research Institute of Horticulture in Skierniewice with overhead irrigation, near Anemone hupehensis (Lemoine) Lemoine, cultivar Prinz Heinrich, infected by Aphelenchoides fragariae. In September of 2014 the leaves of a silver birch seedling characterized by brown necrotic areas associated

\footnotetext{
* - corresponding author
} 

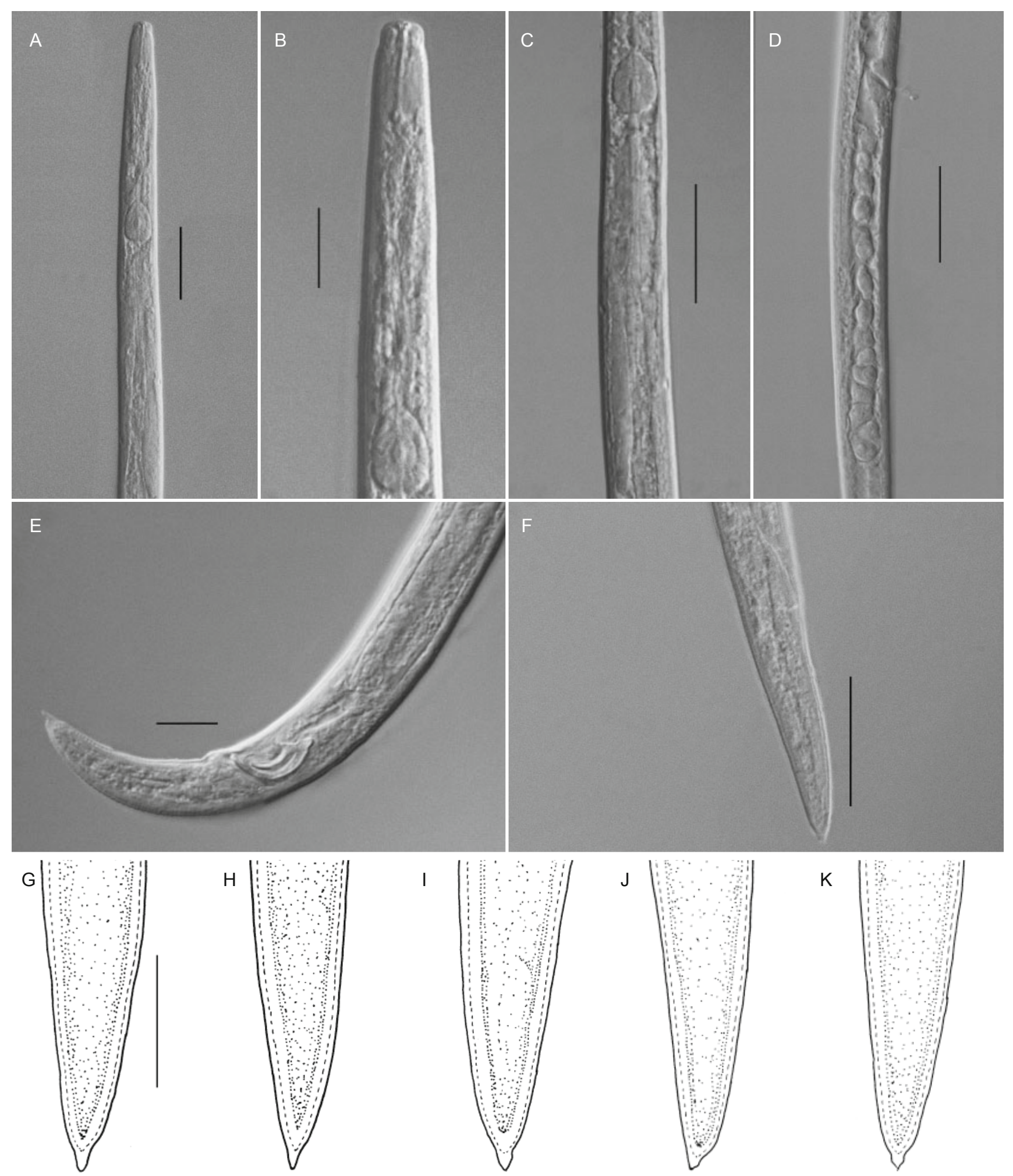

Fig. 1. Photomicrographs of Aphelenchoides fragariae. A) Anterior region of male. B) Anterior region of female. C) Female posterior part of pharynx, basal bulb and pharyngeal gland. D) Female reproductive system, vulva and postvulval uterine sac. E) Male posterior region showing spicules. F) Female tail. G)-K) Female tail, variability in the mucron shape . (Scale bars: A, C, D, F $=20 \mu \mathrm{m}, \mathrm{B}, \mathrm{E}, \mathrm{G}-\mathrm{K}=10 \mu \mathrm{m}$ ). 
with the major veins were collected and examined for the presence of nematodes. The plant was part of a group of seedlings grown on the experimental field of the Research Institute of Horticulture in Skierniewice with overhead irrigation, near plants of Anemone hupehensis (Lemoine) Lemoine cultivar Prinz Heinrich. The A. hupehensis plants were found to be infected by $A$. fragariae after a routine analysis performed to phytosanitary condition of plants. The nematodes were isolated from the leaves by a modified technique of Baermann method (Szczygieł, 1966). The extracted population of nematodes was fixed partly in TAF (97 ml of formalin,
$2 \mathrm{ml}$ of triethanolamine and $91 \mathrm{ml}$ of $\mathrm{dH}_{2} \mathrm{O}$ ) (Courtney et al., 1955) for morphological observations and partly in DESS (20\% dimethyl sulphoxide, $0.25 \mathrm{M}$ disodium EDTA, saturated with $\mathrm{NaCl}$ ) (Yoder et al., 2006) for molecular analyses. To determine the morphometric parameters, 60 nematodes (30 females and 30 males) were processed by Seinhorst's rapid method (Seinhorst, 1959) and mounted in dehydrated glycerin on glass slides. The observations of adults were made using a Nikon Eclipse 80i microscope equipped with a Nomarski differential interference contrast.

Table 1. Measurements of adults of $A$. fragariae. Length values are in $\mu \mathrm{m}$. Average $\pm \mathrm{SD}$ and minimum and maximum values are given.

\begin{tabular}{|c|c|c|c|c|}
\hline Measurements $[\mu \mathrm{m}]$ & $\begin{array}{c}\text { Anemone hupehensis } \\
\text { o } 9 \mathrm{n}=30\end{array}$ & $\begin{array}{c}\text { Anemone hupehensis } \\
\qquad \hat{0} n=30\end{array}$ & $\begin{array}{l}\text { Betula pendula } \\
\text { 우 } \mathrm{n}=30\end{array}$ & $\begin{array}{c}\text { Betula pendula } \\
\partial^{\lambda} \delta^{\lambda} n=30\end{array}$ \\
\hline$L$ & $\begin{array}{c}706.2 \pm 52.6 \\
617.2-814.2\end{array}$ & $\begin{array}{c}605.9 \pm 44.9 \\
485.8-673.6\end{array}$ & $\begin{array}{c}701.8 \pm 38.1 \\
609.1-776.9\end{array}$ & $\begin{array}{r}645.4 \pm 30.6 \\
532.5-645.4\end{array}$ \\
\hline a & $\begin{array}{c}54.3 \pm 3.7 \\
47.5-63.9\end{array}$ & $\begin{array}{c}48.6 \pm 3.9 \\
38.9-57.1\end{array}$ & $\begin{array}{l}51.9 \pm 3.5 \\
46.4-60.1\end{array}$ & $\begin{array}{r}45.9 \pm 2.3 \\
41.6-50.5\end{array}$ \\
\hline$b^{\prime}$ & $\begin{array}{l}4.5 \pm 0.4 \\
3.7-5.6\end{array}$ & $\begin{array}{l}3.8 \pm 0.4 \\
2.9-4.4\end{array}$ & $\begin{array}{l}4.5 \pm 0.4 \\
3.8-5.3\end{array}$ & $\begin{array}{l}3.6 \pm 0.2 \\
3.3-4.0\end{array}$ \\
\hline c & $\begin{array}{l}17.6 \pm 1.6 \\
15.0-22.6\end{array}$ & $\begin{array}{c}19.3 \pm 2.2 \\
14.9-25.6\end{array}$ & $\begin{array}{c}17.6 \pm 1.3 \\
14.7-20.00\end{array}$ & $\begin{array}{l}18.3 \pm 1.8 \\
15.7-23.3\end{array}$ \\
\hline$c^{\prime}$ & $\begin{array}{l}4.5 \pm 0.4 \\
3.4-5.5\end{array}$ & $\begin{array}{l}3.0 \pm 0.3 \\
2.5-3.4\end{array}$ & $\begin{array}{l}4.3 \pm 0.3 \\
3.7-4.8\end{array}$ & $\begin{array}{l}3.1 \pm 0.2 \\
2.7-3.6\end{array}$ \\
\hline Stylet length & $\begin{array}{c}12.1 \pm 0.5 \\
11.1-12.9\end{array}$ & $\begin{array}{c}11.8 \pm 0.4 \\
11.1-12.6\end{array}$ & $\begin{array}{r}12.4 \pm 0.3 \\
11.8-12.9\end{array}$ & $\begin{array}{c}12.1 \pm 0.4 \\
11.2-12.8\end{array}$ \\
\hline $\begin{array}{l}\text { Pharynx length (with } \\
\text { glands) }\end{array}$ & $\begin{array}{c}58.3 \pm 9.7 \\
143.00-174.2\end{array}$ & $\begin{array}{c}161.0 \pm 9.2 \\
146.8-174.6\end{array}$ & $\begin{array}{c}154.4 \pm 12.8 \\
133.5-177.5\end{array}$ & $\begin{array}{c}165.2 \pm 7.1 \\
153.6-179.5\end{array}$ \\
\hline $\begin{array}{l}\text { Excretory pore from head } \\
\text { end }\end{array}$ & $\begin{array}{r}91.6 \pm 4.9 \\
85.1-99.9\end{array}$ & $\begin{array}{c}89.9 \pm 2.1 \\
85.2-96.7\end{array}$ & $\begin{array}{c}93.9 \pm 6.2 \\
82.3-102.5\end{array}$ & $\begin{array}{l}91.4 \pm 4.0 \\
86.0-99.6\end{array}$ \\
\hline Head-vulva length & $\begin{array}{r}524.4 \pm 45.8 \\
437.4-645.7\end{array}$ & - & $\begin{array}{r}518.3 \pm 31.0 \\
450.1-566.1\end{array}$ & - \\
\hline Vulva-anus length (v-a) & $\begin{array}{l}181.9 \pm 15.2 \\
153.6-206.0\end{array}$ & - & $\begin{array}{c}182.2 \pm 12.3 \\
156.2-199.6\end{array}$ & - \\
\hline Maximum body diameter & $\begin{array}{c}13.0 \pm 0.8 \\
11.8-15.00\end{array}$ & $\begin{array}{r}12.7 \pm 0.6 \\
11.7-13.7\end{array}$ & $\begin{array}{l}13.5 \pm 0.8 \\
12.1-14.8\end{array}$ & $\begin{array}{c}13.1 \pm 0.8 \\
11.7-15.00\end{array}$ \\
\hline Tail length & $\begin{array}{c}40.3 \pm 2.8 \\
35.1-45.4\end{array}$ & $\begin{array}{r}31.6 \pm 2.5 \\
26.3-36.6\end{array}$ & $\begin{array}{l}40.00 \pm 2.7 \\
34.7-44.7\end{array}$ & $\begin{array}{l}33.0 \pm 3.0 \\
24.3-37.2\end{array}$ \\
\hline Anal body diameter & $\begin{array}{c}9.0 \pm 0.7 \\
7.8-10.8\end{array}$ & $\begin{array}{l}10.4 \pm 0.6 \\
9.4-11.8\end{array}$ & $\begin{array}{l}9.4 \pm 0.7 \\
8.3-10.8\end{array}$ & $\begin{array}{l}10.7 \pm 0.8 \\
8.4-12.00\end{array}$ \\
\hline $\begin{array}{l}\text { Postvulval uterine sac } \\
\text { (PUS) }\end{array}$ & $\begin{array}{l}93.00 \pm 4.7 \\
84.3-101.6\end{array}$ & - & $\begin{array}{c}94.6 \pm 9.8 \\
75.5-111.0\end{array}$ & - \\
\hline PUS- $\%$ v-a & $\begin{array}{c}50.3 \pm 4.7 \\
43.7-59.00\end{array}$ & - & $\begin{array}{c}52.1 \pm 3.6 \\
46.2-60.7\end{array}$ & - \\
\hline PUS-xV & $\begin{array}{l}7.1 \pm 0.4 \\
6.3-7.9\end{array}$ & - & $\begin{array}{l}7.1 \pm 0.8 \\
5.3-8.6\end{array}$ & - \\
\hline V\% & $\begin{array}{l}74.2 \pm 1.8 \\
69.8-80.0\end{array}$ & - & $\begin{array}{l}74.00 \pm 1.2 \\
71.9-77.3\end{array}$ & - \\
\hline Spicule length & - & $\begin{array}{c}18.3 \pm 1.1 \\
16.2-20.8\end{array}$ & - & $\begin{array}{l}18.7 \pm 0.8 \\
17.4-20.3\end{array}$ \\
\hline
\end{tabular}


Molecular characterisation

Species identity and confirmation of the origin of the silver birch infection from anemone was determined by comparison of $28 \mathrm{~S}$ rDNA sequences. Genomic DNA from eight specimens (four from silver birch and four from anemone) was extracted using the Nucleo Spin Tissue XS (Macherey-Nagel, Germany) following the manufacturer's instruction. For each sample, DNA was eluted in $30 \mu \mathrm{H}_{2} \mathrm{O} .3 \mu \mathrm{l}$ of extracted DNA were used as a template for polymerase chain reactions (PCR). PCR primers for conserved regions were designed using the online PRIMER 3 software (http:// primer3.ut.ee) (Untergrasser et al., 2012). D2-D3 expansion segments of the large subunit 28S rDNA were amplified using primers Aph_F (5'-AGAGAGTGCAAGAGAACGTGA-3') and Aph_R (5'-ACCATCTTTCGGGTCTCAAA-3') (Sigma-Aldrich, Milwaukee, WI, USA). Amplification of $28 \mathrm{~S}$ rDNA and sequencing were performed as described before (Dobosz et al., 2013), but using another polymerase (12,5 $\mu$ l Taq PCR Master Mix Gdansk, Poland) and primer concentration ( $1 \mu \mathrm{l}$ of $10 \mu \mathrm{M}$ for each primer). Cycling was performed on Veriti 96-Well Thermal Cycler (Applied Biosystems, Foster City, CA, USA) with the following cycling conditions: 3 min of initial denaturation at $94^{\circ} \mathrm{C}$, followed by 40 cycles of $94^{\circ} \mathrm{C}$ for 30 $\mathrm{s}, 58^{\circ} \mathrm{C}$ for $30 \mathrm{~s}, 72^{\circ} \mathrm{C}$ for $1 \mathrm{~min}$ and a final extension step of $72^{\circ} \mathrm{C}$ for $5 \mathrm{~min}$. Sequences of 28S rDNA of $A$. fragariae were aligned by ClustalW (Larkin et al., 2007) in MEGA ver. 6.06 using default parameters (Tamura et al., 2011). Automatic alignment was then improved manually in order to eliminate improper phylogenetic signals. For choosing the substitution model, data were analysed by jModelTest 2.1.2 (http://jmodeltest.org) program (Darriba et al., 2012). The program showed that the best substitution model was $\mathrm{GTR}+\mathrm{I}+\mathrm{G}$, which was then used for analysis. Phylogenetic tree was constructed for 28S rDNA using maximum likelihood method with MEGA ver. 6.06 software (Tamura et al., 2011) and compared with their corresponding published gene sequences (Kanzaki et al., 2008, Zhao et al., 2008). New sequences for $A$. fragariae were deposited in the GenBank under the following accession numbers: KP835683-KP835687 from silver birch and KT261768-KT261770 from anemone.

\section{Results and Discussion}

Morphological data and characters of 30 females and 30 males isolated from leaves of silver birch seedling were consistent with description of $A$. fragariae given by Allen (1952), Franklin (1965, 1978), Siddiqi (1974), Chizhov et al., (2006), Andrássy (2007) and Khan et al. (2007b, 2008).

The population of nematodes in the sample was composed of $64 \%$ females, $11 \%$ males and $25 \%$ juvenile forms. No other nematode species were detected in the analyzed material. The most important diagnostic characters of females and males for species identification are reported in Table 1 and illustrated in Fig. 1.

Females of $A$. fragariae from leaves of silver birch seedling are characterised by a slender body, slightly ventrally arcuate when killed; lateral field with two incisures occupies about one-seventh of the body width; lip region almost continuous with body contour, straight to slightly rounded, without visible annulation; weakly sclerotized cephalic framework; thin stylet with small but distinct basal knobs (Fig. 1 B); ovoid, highly muscular median bulb; pharyngeal glands forming long lobe extending intestine dorsally (Fig. 1C); excretory pore level with, or close behind, nerve ring; oocytes arranged in a single row; relatively long postvulval uterine sac, taking more than half of the vulva-anus distance, often containing sperm (Fig. 1D); elongate-conoid, almost straight tail; tail end with single mucron (Fig. 1F), which shape varied, from slightly offset, simple peg to irregularly terminated, less or more enlarged in the half of the length or cut from the dorsal side with almost ventrally located tip (Fig. 1G-K).

Males lip region, stylet and pharynx as in females (Fig. 1A); body slender, ventrally curved in posterior part; tail conoid, arcuate through $45-90^{\circ}$, bearing a terminal peg; spicules prominent, ventrally arcuate, with moderately developed apex and rostrum (Fig. 1E).

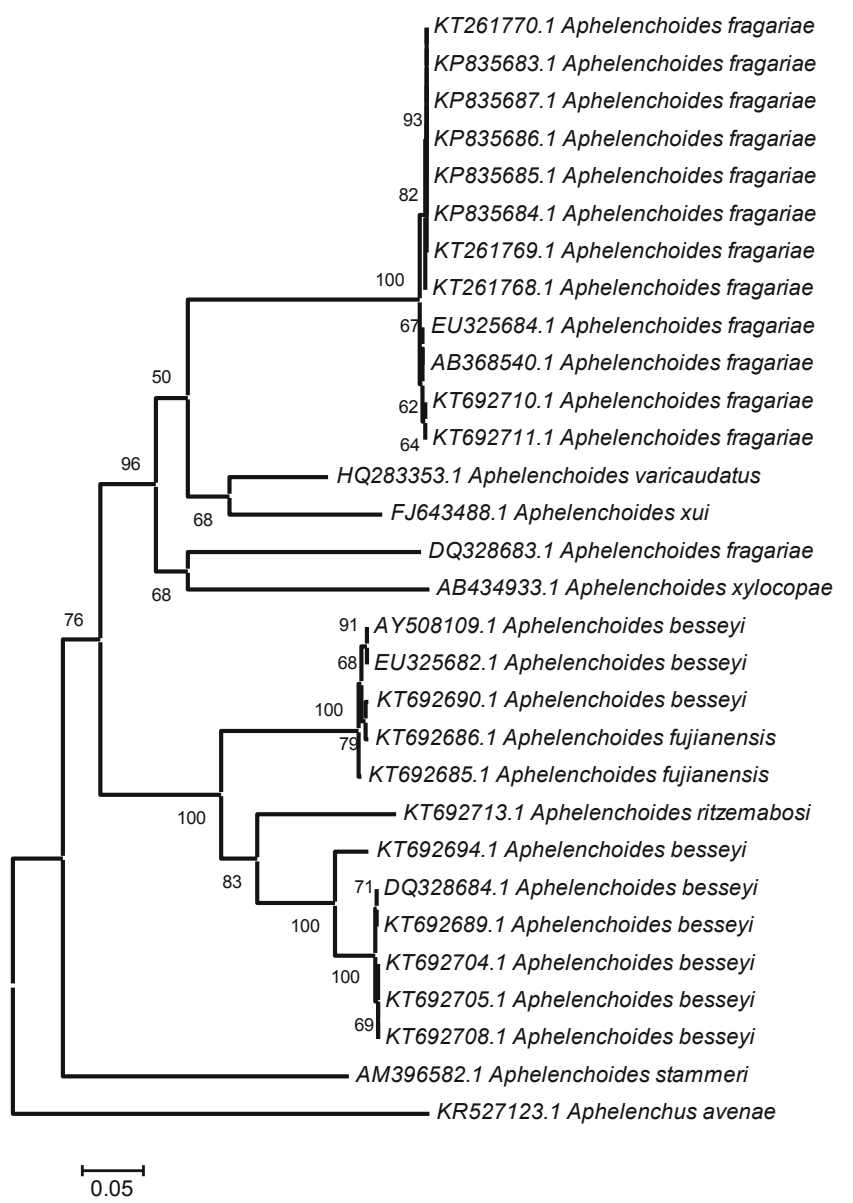

Fig. 2. Phylogenetic relationships within the species of Aphelenchoides fragariae. Maximum likelihood tree inferred from 28S rDNA for Aphelenchoides species with Aphelenchus avenae as the outgroup. 


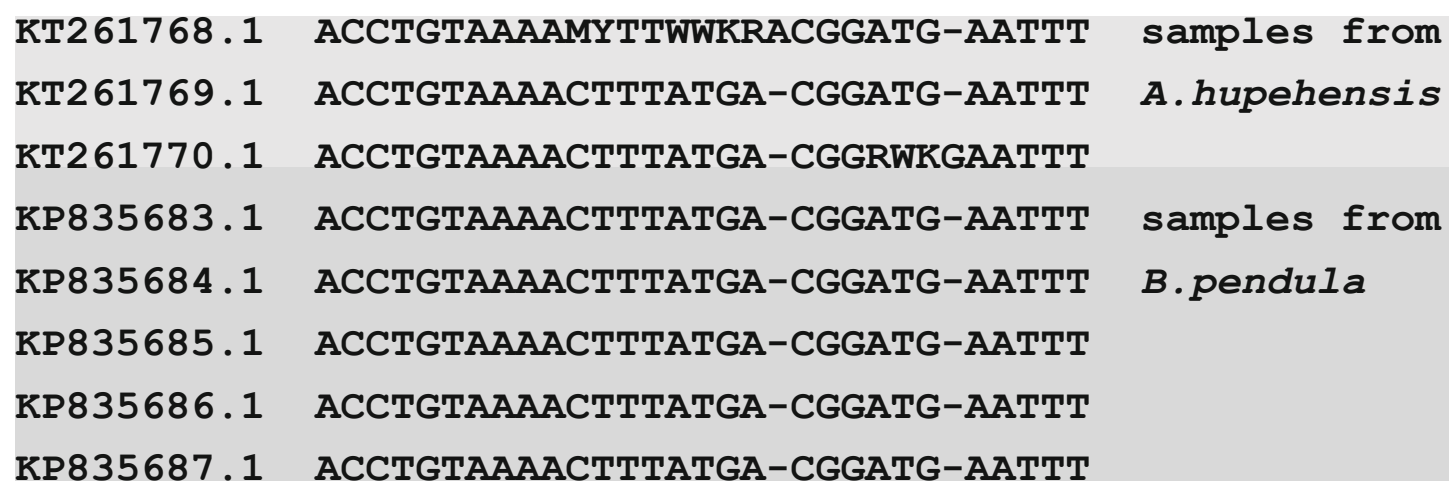

Fig. 3. Comparison of $28 \mathrm{~S}$ rDNA sequences of Aphelenchoides fragariae samples isolated from $A$. hupehensis and B.pendula (only partial 28S rDNA sequences with visible nucleotide insertions/deletions are shown).

This species resembles other Aphelenchoides species occurring in leaves. However, due to the two incisures in lateral fields, the shape of the mucron, the distinctive construction of the head and more prominent apex and rostrum in male spicules, can be differentiate from $A$. ritzemabosi and $A$. besseyi.

For the population of $A$. fragariae obtained from silver birch the value of the mucron as a reliable differentiating character was doubtful because mucron of some females had been confusingly similar to other Aphelenchoides species, including A. ritzemabosi. The same conclusion were drawn by Franklin (1978). Proper identification required analysis of other morphological features of the specimens. The most accurate diagnosis was based on bending the tail of males and pronounced apex and rostrum, forming the proximal part of spicules in ear-like shape.

The length of sequenced 28S rDNA D2-D3 region ranged from $516 \mathrm{bp}$ to $521 \mathrm{bp}$. Phylogenetic trees generated from this region showed that sequences of samples isolated from silver birch and from anemone grouped together with sequences of $A$. fragariae deposited in the GenBank by Kanzaki et al. (2008) as well as Zhao et al. (2008) (Fig. 2). The comparison of 28S rDNA sequences of nematodes isolated from silver birch and anemone revealed high similarity and differed only by two nucleotide substitution (Fig. 3), which probably reflect sequence variability in the population. Results of molecular analysis confirmed that nematodes feeding on anemone were the source of infection for the birch.

A. fragariae infects the leaves of plants by migrating up the stem and entering their stomata. The nematodes spread by migrating through films of water over plant surfaces (Klingler, 1970). Plants moistened by dew, rain or overhead irrigation are the most susceptible to infection, because the nematodes move by splash dispersal from plant to plant (Lehmann, 1996; Kohl et al., 2010). Reports about nematodes found in the above-ground part of hardwood trees are scant. Santamour and McArdle (1987) isolated a species of Aphelenchoides resembling $A$. fragariae from burls of red maple (Acer rubrum L.), Higan cherry (Prunus subhirtella Mig.), red oak (Quercus rubra L.), black locust (Robinia pseudoacacia L.), Siberian elm (UImus pumila L.) and from Cornus florida L. cankers. McCuiston et al. (2007) and Kohl et al. (2010) reported isolation of $A$. fragariae from woody ornamental plants Lantana camara $\mathrm{L}$. and Buddleja davidii Franch. Morphometric comparison of nematodes from silver birch seedlings and anemone showed subtle dissimilarities (Table 1), mainly in the length of males body. Males isolated from $B$. pendula had a longer body length. The differences between the compared populations may arise from a variety of external factors i.a. species of host. Such differences were also noted by Wu (1960) in his study during the Ditylenchus destructor Thorne, 1945 survey. He observed that parameters such as the body width and length, pharynx and stylet length are dependent on the host plant. Similar results were obtained by El-Sherif (1972) with respect to A. sacchari Hooper, 1958 and A. rutgersi Hooper \& Myers 1971.

Detection of $A$. fragariae in a new plant - silver birch - extends the wide host range of this nematode. The results show that nematodes can infect woody plants from perennials located in their vicinity. This is the first report to our best knowledge showing that the source of nematode infection of a woody plant could be a perennial plant. This observation highlights the importance of controlling this foliar nematode in nurseries. Both the morphological and molecular analysis are crucial to properly identify $A$. fragariae, because the characteristic symptoms of the feeding of this species observed on infected leaves are not only specific for this foliar nematode.

\section{Acknowledgement}

This work was done as part of the Innovative Economy Operational Programme conducted by the Museum and Institute of Zoology, Polish Academy of Sciences. Project No. WNDPOIG.01.03.01-00-133/09 co-financed by the European Union from the European Regional Development Fund.

\section{References}

Allen, M.W. (1952): Taxonomic status of the bud and leaf nematodes related to Aphelenchoides fragariae (Ritzema Bos, 1891). Proceedings of the Helminthological Society of Washington, 19(2): $109-120$ 
AndRÁssy, I. (2007): Free-living nematodes of Hungary (Nematoda errantia), II. In:. Csuzdı, C., MahunKa, S. (Eds.). Pedozoologica Hungarica. Volume 4. Budapest, Hungary: Hungarian Natural History Museum, pp. 496

Chizhov, V.N., Chumakova, O.A, Subbotin, S.A., Baldwin, J.G. (2006): Morphological and molecular characterization of foliar nematodes of the genus Aphelenchoides: $A$. fragariae and $A$. ritzemabosi (Nematoda: Aphelenchoididae) from the main botanical garden of the Russian Academy of Sciences, Moscow. Russ. J. Nematol., 14(2): 179 - 184

Courtney, W.D., Polley, D., Miller, V.L. (1955): TAF, an improved fixative in nematode technique. Pl. Dis. Reptr., 39: 570 - 571

Darriba, D., Taboada, G.L., Doallo, R., Posada, D. (2012): jModelTest 2: more models, new heuristics and parallel computing. Nat. Methods, 9(8): 772. DOI: 10.1038/nmeth.2109

Dobosz, R., WiniszeWska, G., MaleWski, T., RybarczYk-Mydıowska, K., Tereba, A., Kowalewska, K., Gawlak, M., Bogdanowicz, W. (2013): Morphological and molecular features of Punctodera stonei Brzeski, 1998 (Nematoda: Heteroderidae) - species associated with roots of grasses. Ann. Zoolog., 63: 157-162. DOI: $10.3161 / 000345413 \times 669487$

EL-SHERIF, A.G. (1972): The influence of host nutrition on the morphometrics of three Aphelenchoides species (Nematoda: Aphelenchoidea). Nematol., 18: 174 - 178. DOI: 10.1163/187529272X00412

FrankLIn, M.T. (1965): Aphelenchoides. In: Southey, J. F. (Ed) Plant Nematology. London, UK: Her Majesty's Stationery Office, pp. $131-141$

FrankLIN, M.T. (1978): Aphelenchoides and related genera. In: SoutheY, J.F. (Ed) Plant Nematology. London, UK: Her Majesty's Stationery Office, pp. $172-187$

Hunter, J.E., Ko, W.H., Kunimoto, R.K., Higakı, T. (1974): A foliar disease of anthurium seedlings caused by Aphelenchoides fragariae. Phytopathol., 64(2): 267 - 268. DOI: 10.1094/Phyto-64-267

Kanzaki, N., Giblin-Davis, R.M., Cardoza,Y.J., Ye,W., Raffa, K.F. Center, B.J. (2008): Bursaphelenchus rufipennis n. sp. (Nematoda: Parasitaphelenchinae) and redescription of Ektaphelenchus obtusus (Nematoda: Ektaphelenchinae), associates from nematangia on the hind wings of Dendroctonus rufipennis (Coleoptera: Scolytidae). J. Nematol., 10: 925 - 955. DOI: 10.1163/156854108786161517

Khan, Z., Son, S.H., Moon, H.S., KIm, S.G., Shin, H.D., Kim, Y.H. (2007a): The foliar nematode, Aphelenchoides fragariae, on Jerusalem artichoke (Helianthus tuberosus) and Weigela (Weigela subsessilis). Nematrop., 37: 335 - 337

Khan, Z., Son, S.H., Moon, H.S., KIM, S.G., ShIn, H.D., JeON, Y.H., KIM, Y.H. (2007b): Description of a foliar nematode, Aphelenchoides fragariae (Nematoda: Aphelenchida) with additional characteristics from Korea. J. Asia-Pacific Entomol., 10(4): 313 - 315. DOI: 10.1016/S1226-8615(08)60368-4

KHAN, Z., Son, S.H., Shin, H.D., KIm, Y.H. (2008): First report of foliar nematode Aphelenchoides fragariae (Aphelenchidae) on
Stachys riederi var. japonica, a Medicinal Plant, in Korea. Plant Pathol. J., 24(1): 97 - 100. DOI: 10.5423/PPJ.2008.24.1.097

KLINGLER, J. (1970): The reaction of Aphelenchoides fragariae to slit-like micro-openings and to stomatal diffusion gases. Nematology, 16(3): 417 - 422. DOI: 10.1163/187529270X00126

Kohl, L.M., Warfield, C.Y., Benson, D.M. (2010): Population dynamics and dispersal of Aphelenchoides fragariae in nursery-grown lantana. J. Nematol., 42(4): 332 - 341.

LAMondiA, J.A., OcAmB, C.H. (1995): First report of the foliar nematode Aphelenchoides fragariae infecting Lamium. Plant Dis., 79(6): 642. DOI: 10.1094/PD-79-0642A

Larkin, M.A., Blackshields, G., Brown, N. P., Chenna, R., McGettigan, P.A., McWilliam, H., Valentin, F., Wallace, I.M., Wilm, A., Lopez, R., Thompson, J.D., Gibson, T.J., Higgins, D.G. (2007): Clustal W and Clustal X version 2.0. Bioinform., 23: 2947 - 2948. DOI: 10.1093/bioinformatics/btm404

LeHMANN, P.S. (1996): Dispersal modes for foliar nematodes. Report 216. Nematol. Circ., Florida Dept. of Agric. and Consumer Serv., Gainesville, FL.

McCuiston, J.L., Hudson, L.C., Subbotin, S.A., Davis, E.L., WarfIELD, C.Y. (2007): Conventional and PCR Detection of Aphelenchoides fragariae in Diverse Ornamental Host Plant Species. J. Nematol., 39(4), 343 - 355

NoEl, G.R., White, D. (1994): A new host record for Aphelenchoides fragariae. Plant Dis., 78(9): 924. DOI: 10.1094/PD-78-0924C

Penrose, L.J., Nikandrow, A. (1971): Ficus macrophylla, a new host for Aphelenchoides fragariae (Ritzema Bos) Christie. Search, 2(5): 170

SANTAmour, F.S. JR., McArdle, A.J. (1987): Association of nematodes with dogwood canker and stem malformation of other trees. J. Environ. Hortic., 5: 136 - 140

SEINHORST, J.W. (1959): A rapid method for the transfer of nematodes from fixative to anhydrous glycerin. Nematology, 4: $67-69$. DOI: 10.1163/187529259X00381

Self, L. H., Bernard, E. C. (1994): Association of nematodes and dogwood cankers. J. Nematol., 26(1): 59 - 64

SIDDIQI, M.R. (1974): Aphelenchoides fragariae. In: Descriptions of Plant-parasitic Nematodes. Set 5, No. 74. St. Albans, UK: CAB International, pp. 4

SzczYGIEt, A. (1963): Występowanie i szkodliwość węgorka truskawkowca (Aphelenchoides fragariae) oraz węgorka chryzantemowca (A. ritzemabosi) na truskawkach w Południowej Polsce [The occurrence and harmfulness of the strawberry foliar nematode (Aphelenchoides fragariae) and the chrysanthemum foliar nematode (A. ritzemabosi) on strawberries in South Poland]. Biuletyn IOR, 21: 109 - 116

SzCzYGIEk, A. (1966): Studies on the fauna and population dynamics of nematodes occurring on strawberry plantations. Ekol. Pol., Ser. A, 13: $651-709$.

SzCZYGIEt, A. (1970): Distribution of leaf and bud nematodes (Aphelenchoides spp.) and stem nematode (Ditylenchus dipsaci) in strawberry fields in Poland. Zesz. Probl. Post. Nauk Roln., 92: 321 - 329 
Tamura, K., Peterson, D., Peterson, N., Stecher, G., Nei, M., KuMAR, S. (2011): MEGA5: Molecular evolutionary genetics analysis using maximum likelihood, evolutionary distance and maximum parsimony methods. Mol. Biol. Evol., 28: 2731 - 2739. DOl: 10.1093/molbev/msr121

Untergrasser, A., Cutcutache, I., Koressaar, T., Ye, J., Faircloth, B. C., Remm, M., Rozen, S. G. (2012): Primer3 - new capabilities and interfaces. Nucleic Acids Res., 40(15): e115. DOI: 10.1093/ nar/gks596

Wu, L. Y. (1960): Comparative study of Ditylenchus destructor Thorne, 1945 (Nematoda: Tylenchidae) from potato, bulbous iris and dahlia with a discussion of De Man's ratios. Canad. J. Zoolog., 38: 1176 - 1187. DOI: 10.1139/z60-122

Yoder, M., De Ley, I. T., King, I., Mundo-Ocampo, M., Mann, J., BlaXTER, M., PoIRAs, L., De Ley, P. (2006): DESS: A versatile solution for preserving morphology and extractable DNA of nematodes. Nematology, 8: 367-376. DOI: 10.1163/156854106778493448

Zhao, Z.Q., Ye, W.M., Giblin-Davis, R.M., LI, D. M., Thomas, W.K., DAVIES, K., RILEY, I.T. (2008): Morphological and molecular analysis of six aphelenchoidoids from Australian conifers and their relationship to Bursaphelenchus (Fuchs, 1937). Nematology, 10 (5): 663 - 678. DOI: 10.1163/156854108785787299 